\title{
Community preparedness toward flood during Covid-19 pandemic at Pekalongan City and Regency
}

\author{
Gardena Smoro Laksmi ${ }^{1 *}$, Iwan Rudiarto ${ }^{2}$, Yanuar Luqman ${ }^{2}$ \\ ${ }^{1}$ Master of Environmental Science, Postgraduate School, Diponegoro University, Semarang, \\ Indonesia \\ ${ }^{2}$ Lecturer of Environmental Science, Postgraduate School, Diponegoro University, Semarang, \\ Indonesia
}

\begin{abstract}
Several countries experience difficulties in overcoming the effects of natural disasters amid the Covid-19 pandemic, such as Typhoon Hagibis in Japan, floods due to melting snow in Canada, Typhoons in Bangladesh, and Cyclone Harold in Pacific countries. Natural disasters that affected the world during infectious diseases did not only occur in 2020. Earthquakes struck Haiti during the 2010 Cholera epidemic outbreak and respiratory infections during the Great East Japan Earthquake and Tsunami in 2011. Something similar happens in Indonesia, one of which is flood and tidal flood in Pekalongan that occur during the Covid-19 pandemic. This study reviews the efforts of countries in overcoming natural disasters during the pandemic. It aims to propose an approach for flood disasters preparedness in Pekalongan so that disaster preparedness process including victim evacuation, can be done without increasing the spread of Covid-19. Information about humanity, disaster management, health, water and sanitation that are disseminated to the public must be supported by scientific knowledge to avoid the spread of myths and negative stigma. Coordination between stakeholders and the local community plays the most important role in flood disaster preparedness with the Covid-19 protocol during the pandemic.
\end{abstract}

Keywords. Covid-19, flood, preparedness, Pekalongan

\section{Introduction}

Indonesia experiences difficulties in overcoming the effects of natural disasters amid the Covid-19 pandemic, one of which is Flood in Pekalongan. Rain and sea-level rise cause flooding every year. Flood caused the village sink phenomenon in January 2019 and continued until 2020 during the Covid-19 pandemic [1]. Pekalongan City and Regency are included in a vulnerable area of climate change. All villages in North Pekalongan Regency are flooded which is 1249.420 hectares [2]. Flooding in Pekalongan Regency since January

* Corresponding author: slgardena@gmail.com 
2020 occurred in eighteen villages. The rivers can't accommodate high-intensity rainfall and cause 20-30 cm puddles. Based on the disaster potential map, Bojong, Buaran, Kedungwuni, Siwalan, Sragi, Tirto, Wiradesa, Wonokerto, and Wonopringgo are included in the category of flood or tidal flood-prone are [3], but some high-level tidal flood-prone areas still designated as industrial estates or residential areas [4]. Tidal flooding is caused by sea-level rise and exacerbated by land subsidence due to groundwater exploitation [5]. Many illegal boreholes in tidal flood-prone areas are used for agriculture, industry, and community needs [6]. Land subsidence caused by illegal boreholes is the main cause of inundation areas [7].

On the other hand, 21 July 2020, 18 Pekalongan City people were confirmed positive of Covid-19, 6 patients under supervision, and 223 persons under monitoring [8]. On the same date, 28 Pekalongan Regency people were confirmed positive of Covid-19, 47 patients under supervision, and 612 persons under monitoring. Disaster during this pandemic requires community preparedness [9]. BPBD of Pekalongan Regency prepares equipment and evacuation officers, conducts an assessment to the location of the flood, evacuating victims, and cooperates with villages to set up public kitchens in Mejasem, Sragi, and Simbangkulon Village [3], but new policies and approaches are needed. Low preparedness can increase Covid-19 transmission, and losses both human and economic. On the other hand, excessive Covid-19 protocol can cause delays in saving victims and increase the flooding damage. This study reviews various efforts during the Covid-19 pandemic. It aims to propose an approach based on the review, so that disaster preparedness include victim evacuation can proceed without increasing the spread of Covid-19.

\section{Materials and method}

This research is a literature study that collects data and information from various journals and bulletins relating to infectious diseases during natural disasters. It uses comparative historical research and environmental approaches. The results will be discussed descriptively and explained according to the method suitable for the aim.

\section{Result and discussion}

\subsection{Flood preparedness at Pekalongan}

Disaster preparedness indexes by UNESCO / ISDR (2006) are divided into knowledge and attitudes, institutional mitigation, emergency response, early warning system, and resource mobilization [10]. Based on the knowledge and attitude index, the Pekalongan City people are almost ready. They know that land subsidence worsens flooding and the causes of flooding. People do not believe the myths associated with flooding. But, the majority of people did not know the flood period and inundation duration. While in terms of institutional mitigation, communities receive logistical support, clothing, medicines, and shelter during floods through rescue teams from government, non-governmental organizations, and even individuals. The aid is distributed directly or taken by member representatives.

For emergency response, the community is trying to raise the house floor for about 50$100 \mathrm{~cm}$ every five years. When the flood height exceeds $70 \mathrm{~cm}$ and does not recede within six hours, seventy percent of people choose to evacuate their family members, while the rest choose to stay at home because they want to protect their property. The government is preparing evacuation sites in public facilities such as sports buildings, mosques, school buildings, and health buildings because these buildings floors are always raised 
periodically. The victims' evacuation was carried out by rescue workers from the government and volunteers.

On the other hand, Pekalongan City's early warning system is not good enough. Seventy percent of the community said that there had been no announcement or warning when the flood started, while thirty percent of the community said that warning is given through the kentongan (traditional bamboo alarm), mosque speakers, and school speakers. Warning that delivered via WhatsApp and text messages has been done personal, not structured nor organized well. There are no posters, path instructions, and evacuation directions in public places or in government offices. The evacuation site is announced by officers through a radio broadcast. The early warning system and resource mobilization level are almost similar. Resource mobilization of Pekalongan City is weak [1].

\subsection{Disaster preparedness of several countries}

Tropical Cyclone Harold hit four Pacific Island nations in April 2020. Fiji, Solomon, Tonga, and Vanuatu destroyed by TC Harold during the pandemic. The United Nations and UNICEF are coordinated to overcome TC Harold. UNICEF provides technical assistance such as water and sanitation needs, health assistance, nutrition, and shelter in Vanuatu and Fiji. However, due to Covid-19, the Vanuatu Government doesn 't allow foreigners to enter the country and mandates that all humanitarian cargo undergo strict health protocols before being demoted[11]. To prevent the spread of Covid-19, Vanuatu reduced restrictions on international aid supplier cargoes while continuing to implement Covid-19 control measures. Before moving items from the port, cargo pallets must be sprayed with disinfectants like an ammonium solution. Then they sterilize the worker's items separately and left it for 36 hours or more. The Vanuatu Red Cross has socialized about 5,000 households on awareness of safe havens to prevent the surge of victims in evacuation centers that could increase the spread of Covid-19. On the other hand, IDMC reports that cases of gender-based violence (GBV) are increasing because of minimal lights at the evacuation center. To overcome this problem, the Fiji Women's Crisis Center (FWCC) and the Crisis Center for Women and Children (WCCC) in Tonga developed a strategy. They promote their telephone assistance numbers via social media, television, and radio. For the first time, the Fijian and Tonga conducted online counseling [12].

Similar to Pacific Island, Canada experienced flooding in April 2020. Flood in Manitoba Province caused by snowmelt. They made dykes from sandbags while applying physical distancing of two meters in a circle. Ottawa City formed a separate team to deal with floods in response to the Covid-19 pandemic. Every job is carried out by five people or less. The city government requests relevant organizations and communities to obey the Covid-19 protocol by keeping a distance and doing every work with five people maximum. The Government of Canada has WeatherCAN, a free weather warning application that can be installed on mobile devices. People are encouraged to make contact lists of parties who need to be contacted when an emergency occurs. The government recommends disposing of food include canned food that comes in contact with floodwater. If people want to tidy up flooded items, it is recommended to wear personal protective equipment (PPE) such as gloves, waterproof clothing, masks, and boots. If people cannot get PPE, it is recommended to use whatever they have to protect themselves.

The same thing happened in Japan. Typhoon Hagibis struck all of Japan in October 2019 and caused flooding. The local government reduced voluntary acceptance to prevent the spread of Covid-19 in February 2020. Volunteers normally helped the local communities affected by flooding. Around 200,000 volunteers helped the rehabilitation process, like cleaning building ruins and house renovation. Typhoon Hagibis killed one hundred people, destroyed about sixty thousand houses, and flooded thirty thousand homes. 
The Kamogawa City Government asked the public to deal with heavy rain by doing the Covid-19 protocol in April 2020. The Kamogawa government's requests are to live in a relative's house (not in an evacuation center), stay at home when conditions are safe, avoid crowds in the evacuation centers, and carry out the Covid-19 protocol, like using masks in evacuation places [13].

Natural disasters that affected the world during infectious diseases did not only occur in 2020. Haiti earthquake ( 7 on the Richter scale) in 2010 was followed by a cholera epidemic that killed 7,000 residents including UN aid workers. This disaster is a lesson and warning for countries that want to offer international assistance to the islands in the Pacific during the typhoon season. The similar thing happened in 2011. The spread of infectious diseases during the Great East Japan Earthquake and Tsunami (GEJE) can be used as a reference in responding to Covid-19. Japanese people review measures to prevent and control infectious diseases during the tsunami disaster. The medical team established local coordination at each evacuation site, provided epilepsy drugs, took DVT / PE (deep vein thrombosis and pulmonary embolism) measures, and provided a special place for people with disabilities and the elderly. The medical team surveyed the evacuation site and analyzed the disease there. All aid must be given on time, but needs in the affected areas continue to change, so we have to find an organization or individual who can assist right on time. Therefore, organizations or individuals who have assisted in a previous disaster are listed with their address. A group email was sent to connect them, so the medical team immediately got help when needed. Disaster relief should be listed and saved in a shed so that it can be delivered on time with the right specifications and quantities [14].

\subsection{Revised procedures and standards}

Every country must report to the WHO if two of the four PHEIC criteria occur, which is biological (infectious and zoonotic), food safety, chemical, and radio nuclear. Each country must report to WHO about all these events within 24 hours after they have been confirmed [15]. WHO receives all reports including those from countries that are not members [16]. On 30th January 2020, Dr. Tedros A. Ghebreyesus as a Director-General of WHO announced that the Covid-19 outbreak is a PHEIC. This pandemic is the 6th PHEIC since IHR came into force in 2005 [17]. Under Section 3 of the IHR (2005), countries are given legal authority to quarantine. Quarantine is a people activity limitation who are not sick but potentially contracting the disease. While isolation is the separation of infected people so that transmission does not occur. Quarantine is written in Section 30, 31, and 32 of the IHR framework (2005) concerning people who travel. According to the UN charter, Member states have the sovereign right to make legislation, and implement legislation, for the achievement of their health policies, even though this includes restrictions on the movement of people. WHO recommends that people who come into contact with positive patients Covid-19 should be quarantined for 14 days. This document applies to Covid-19 and other respiratory pathogens such as MERS_CoV, influenza viruses, and SARS-CoV, and will continue to be updated when new information is discovered [18]. WHO guidelines on waste health, water, and sanitation services are relevant for handling viruses, one of which is the Covid-19 virus. Hygienic conditions, the provision of clean water, and sanitation are indispensable in protecting human health from infectious diseases. Implementing WASH practices and managing household, community, market, health facilities and school waste will reduce Covid-19 transmission. This guideline was published in March 2020. This guideline details sanitation, hand hygiene, supports the continuation of WASH services, and protects WASH workers [19].

Besides IHR, Sphere standard is suitable for dealing with Covid-19 with three important interrelated factors that are human dignity, community involvement, and human needs. The 
standard covers the following factors, which are food security, sanitation, and clean water, nutrition, shelter and shelter, food aid, health services, and non-food items. This standard sees people as humans (not cases), community involvement is considered very important, and prevention of the spread of Covid-19 must not forget the needs of victims or the longterm medical needs of a more populous population large. In the case of Ebola (2014) in West Africa, health staffs were diverted and deployed to the handling of Ebola and make the other health cases neglected [20].

The SFDRR and Health-EDRM framework also responds to Covid-19. Health EDRM analyzes health risks caused by disasters and emergencies based on prevention and reduction of risk of danger and vulnerability, preparedness, response, and recovery steps. The United Nations Office for Disaster Risk Reduction (DRR) on Thursday, 12 March 2020 requested that biological hazards be prioritized by disaster management agencies. Emergency health conditions are the top priority, followed by floods, earthquakes, storms, and other natural hazards. Not only The SFDRR, but ASEAN also improve the health sector in the detection, prevention, and response to Covid-19. The specific ASEAN bodies involved were the Senior Health Development Senior Meeting (SOMHD), the ASEAN Regional Center for Virtual Biodioaspora (ABVC), the ASEAN Emergency Operations Center Network for public health emergencies (ASEAN EOC Network), the Republic of Korea, Japan and China (Plus Three Countries) [21].

\section{Conclusion}

The Pekalongan government should increase its preparedness in dealing with floods during the Covid-19 pandemic. Pekalongan has precisely put in place prevention to slow the Covid-19 spreading. However, in overcoming the impact of flooding and evacuation of victims, workers lacked the Covid-19 protocol such as maintaining distance, limiting members of each workgroup, and using masks appropriately. Therefore, the government should take steps in disaster preparedness without ignoring the Covid-19 protocol. The government and the community need to prepare facilities, infrastructure and implement the Covid-19 protocol so that workers and volunteers are protected. When evacuating, workers and volunteers must wear PPE and have PPE reserves. Thermometers must always be provided as a first aid kit. The community should continue using masks, doing physical distancing, and maintaining personal hygiene during evacuations. Therefore, early socialization needs to be done.

\section{References}

[1] F. D. S. Kartika, M. Helmi, and Amirudin, "Meta-analysis of community ' $\mathrm{s}$ adaptation pattern with tidal flood in Pekalongan City , Central Java , Indonesia," ICENIS, vol. 1, no. 2019 , pp. 1-4, (2019).

[2] D. N. Febriani, M. Helmi, and Hariyadi, "Kajian Genangan Banjir Pasang di Kecamatan Pekalongan Utara, Kota Pekalongan,” Oseanografi, vol. 6, no. 4, pp. 579-587, (2017), [Online]. Available: http://ejournals1.undip.ac.id/index.php/jose\%0AKAJIAN.

[3] BPBD Kabupaten Pekalongan, "Info Banjir di Kabupaten Pekalongan," 2020. http://bpbd.pekalongankab.go.id/2020/01/25/info-banjir-kabupaten-pekalongan/.

[4] BAPPEDA Kota Pekalongan, "Laporan Rencana Tata Ruang Wilayah Tahun 2009 2029," 2010. 
[5] F. Dwi et al., "Analisis Perubahan Penggunaan Lahan di Wilayah Pesisir Kota Pekalongan Menggunakan Citra Lansat 8," J. Mar. Res., vol. 2, no. 3, pp. 35-43, (2013), doi: 10.14710/jmr.v2i3.3129.

[6] H. Andreas, H. Z. Abidin, I. Gumilar, T. P. Sidiq, D. A. Sarsito, and D. Pradipta, "Insight into the Correlation between Land Subsidence and the Floods in Regions of Indonesia," Nat. Hazards - Risk Assess. Vulnerability Reduct., 2018, doi:10.5772/intechopen.80263.

[7] BPS Kota Pekalongan, "Kota Pekalongan dalam Angka," pp. 1-431, (2018).

[8] “Kota Pekalongan Tanggap Covid-19.” https://corona.pekalongankota.go.id/.

[9] "Monitoring Penyebaran Virus Covid-19 di Kabupaten Pekalongan." http://corona.pekalongankab.go.id/.

[10] LIPI-UNESCO/ISDR, "Kajian Kesiapsiagaan Masyarakat Dalam Mengantisipasi Bencana Gempa Bumi dan Tsunami," pp. 6-7, (2006), [Online]. Available: www.buku-e.lipi.go.id/utama.cgi?lihatarsip\&jans001\&1273262299\&52.

[11] E. Allen, "Tropical Cyclone Harold and Covid-19: Lessons from The 2010 Haiti Earthquake," Secur. Nexus, pp. 19-21, 2020, doi: 10.1371/journal.ppat.1003967.

[12] “Across the Pacific, Crisis Centres Respond to Covid-19 Amid Natural Disasters," 2020. https://reliefweb.int/report/fiji/across-pacific-crisis-centres-respond-covid-19amid-natural-disasters.

[13] M. Ishiwatari, T. Koike, K. Hiroki, T. Toda, and T. Katsube, "Managing disasters amid COVID-19 pandemic: Approaches of response to fl ood disasters," Prog. Disaster Sci., vol. 6, p. 100096, 2020, doi: 10.1016/j.pdisas.2020.100096.

[14] N. Uehara, "Be prepared! - Lessons learned from the Great East Japan Earthquake and tsunami disaster," Japan Med. Assoc. J., vol. 56, no. 2, pp. 118-126, (2013).

[15] A. Anema, E. Druyts, H. G. Hollmeyer, M. C. Hardiman, and K. Wilson, "Descriptive review and evaluation of the functioning of the International Health Regulations (IHR) Annex 2," Global. Health, pp. 1-9, (2012).

[16] B. M. Meier, D. P. Evans, and A. Phelan, Rights-Based Approaches to Preventing, Detecting , and Responding to Infectious Disease. Springer International Publishing, 2020.

[17] WHO, "2019-nCoV outbreak is an emergency of international concern," 2020. https://www.euro.who.int/en/health-topics/health-emergencies/coronavirus-covid-

19/news/news/2020/01/2019-ncov-outbreak-is-an-emergency-of-internationalconcern.

[18] World Health Organization, "Pertimbangan-Pertimbangan Untuk Karantina Individu Dalam Konteks Penanggulangan Penyakit Coronavirus (COVID-19)," no. 2005, pp. 1-3, (2020), [Online]. Available: https://www.who.int/docs/defaultsource/searo/indonesia/covid19/who-2019-covid19-ihr-quarantine-2020indonesian.pdf?sfvrsn=31d7cbd8_2.

[19] WHO, "Water, Sanitation, Hygiene, and Waste Management for The Covid-19 Virus," World Heal. Organ., no. April, pp. 1-9, (2020).

[20] Sphere, "The Sphere standards and the response to Coronavirus," Sph. Handb., pp. $1-4,(2020)$.

[21] R. Djalante, R. Shaw, and A. Dewit, "Progress in Disaster Science Building resilience against biological hazards and pandemics : COVID-19 and its implications for the Sendai Framework," Prog. Disaster Sci., vol. 6, p. 100080, (2020), doi: 10.1016/j.pdisas.2020.100080. 